\title{
Leder
}

\section{Mangfold og felles utfordringer i anvendt etikk}

\author{
Rune Nydal, Berge Solberg \& Bjorn Myskja
}

Da dette tidsskriftet ble etablert for seks år siden, var det ut fra tanken om at det finnes noen felles problemstillinger innen etikk og politikk som får en spesiell karakter i nordiske land. Den velferdsmodellen vi har utviklet innenfor rammene av et deltakende demokrati, gir vilkår for debatten som vi ikke deler fullt ut med de fleste andre demokrati i verden. Mange av de artiklene vi har trykket i disse årene, har vist betydningen av denne nordiske konteksten. Det gjelder også noen av bidragene i dette nummeret.

Dette nummeret presenterer fem bidrag hentet fra fem ulike temaområder som diskuterer spørsmål av typen: I hvilken grad kan europeiske land stilles til ansvar for urett begått mange tiår tilbake? Bør bransjeetiske retningslinjer få vekt i rettslige resonnementer? Hvordan kan en dyktiggøøre sykepleiere til likebehandling når ens egne fordommer mot marginaliserte grupper først slår inn i en praksissituasjon? Hvilke konfliktfylte beslutningsfaktorer må en bedriftsleder være spesielt oppmerksom på, og hvordan kan en styrke en organisasjons kapasitet til å diskutere organisasjonens formål og utøvelse? Denne sammenstillingen av ulike problemområder demonstrerer det mangfoldet $\mathrm{i}$ anvendt etikk som vi ønsker å presentere i ett og samme tidsskrift. En fordel med et bredt anlagt tidsskrift innenfor anvendt etikk er at utfordringer som deles av ulike grener av feltet, kan bli tydeligere.

Spørsmålene som behandles av forfatterne i dette nummeret, er spørsmål som gjenkjennes som etiske, men som samtidig er utmyntet innenfor ett eller flere fagområder som setter de etiske utfordringene. Selv om de aktuelle etiske problemstillinger kan være svært presserende, er spørsmålene ofte blitt lite systematisk behandlet. Arbeid innenfor anvendt etikk innebærer ofte en type nybrottsarbeid - som vi ser eksempler på i dette nummeret - som det kan være vanskelig å finne et egnet tidsskrift for. Det er heller ikke opplagt hvem som best kan vurdere og fremdyrke denne type faglitteratur ettersom teoritilfanget for anvendt etikk både favner bredt og samtidig alltid krysser over flere fagfelt. Idet normative spørsmål reises, viser det seg ofte vanskelig å avgjøre hvilke fagtradisjoner argumentasjonen burde prøves ut mot.

En av de funksjoner teorier har, er at de er retningsgivende, og de setter måter å se og vurdere fenomener på. Når normative spørsmål reises i en praktisk fagkontekst, reises ikke bare et spørsmål om hvordan og hvilke normative perspektiver som bør tilføres. Det reises også et spørsmål til det aktuelle fagperspektivets normative forutsetninger. Normative diskusjoner synes å måtte utmyntes i skjæringspunktet mellom ulike teoretiske perspektiver, og behandles i spørsmålenes situerte kontekst. Dette utgjør en av de tilbakevendende teoretisk-metodiske utfordringer for anvendt etikk, noe som på ulikt vis blir demonstrert $\mathrm{i}$ artiklene i dette nummeret. 


\section{Artikler i dette nummeret}

Rettferdighet er sentralt i etisk og politisk teori, selv om det fortsatt er stor faglig uenighet om hva begrepet innebærer og under hvilke betingelser man kan fremme rettferdighetskrav. Den grunnleggende analysen av begrepet finner vi hos Aristoteles, som skiller mellom fordelingsrettferdighet og gjenopprettende rettferdighet. Den siste typen rettferdighet dreier seg om å gjenopprette balansen når urett er begått. Dette er utgangspunktet for Göran Collste sin artikkel, «Betydelsen av historisk rättvisa efter kolonialismen». Artikkelen diskuterer hvorvidt det er rimelig å reise rettferdighetsbaserte krav etter overgrep begått av kolonistater mot enkeltpersoner og grupper. Hvem kan reise slike krav, og hvem er ansvarlig for disse overgrepene? Collste diskuterer to historiske hendelser: Storbritannias overgrep under Mau Mau-opprøret i Kenya og det tyske keiserrikets folkemord på Herero-folket i det nåværende Namibia. Ved å analysere disse eksemplene kartlegger Collste sentrale spørsmål og mulige svar på hvordan man kan håndtere rettferdighetskrav som følge av historisk urett.

Børge Aadland undersøker betydningen av en juridisk forankring av profesjonsetiske kodekser i artikkelen «Den rettslige betydningen av yrkesetiske regler med utgangspunkt i lovfestede spesielle god skikk-regler». Aadland sammenligner fem bransjer der yrkesetiske regler har fått en lovmessig forankring ut fra en hypotese om at slike regler vil regulere fem elementer: profesjonsansvar, integritet, objektivitet, taushetsplikt og kompetansekrav. En slik lovfesting av yrkesetiske regler gir anledning til større grad av realitetsbehandling av brudd på yrkesetiske regler, argumenter Aadland. For selv om rettspraksis tyder på at de ulovfestede yrkesregler har hatt betydning for rettsvurderinger, har argumentasjonen i liten grad gitt anledning til innholdsvurdering utover argumentasjon om at forventninger til yrkesutøvere - ut fra en sedvane etablert i yrkeskodekser - må være bindende for domstolene. Gitt denne analysen ser lovregulering ut til å gi domstolen større handlingsrom slik at den kan foreta en selvstendig normativ vurdering av aktørers profesjonelle samfunnsansvar.

Trine Myhrvold diskuterer hvordan man skal bevisstgjøre sykepleiestudenter om de helsemessige utfordringene som kan knyttes til grupper som lever i samfunnets periferi. I artikkelen «Marginalisation as a Possible Health Issue: an Exercise in Practice-Based Ethical Education» beskriver hun et pilotprosjekt der studentene møter representanter for slike marginaliserte grupper og reflekterer over de moralske og politiske plikter de som helsearbeidere - har overfor dem. Dette skjer gjennom en dialogisk tilnærming som involverer frivillige organisasjoner og lavterskeltilbud rettet mot dem som faller utenfor de normale helse- og velferdstilbudene. Pilotprosjektet innebærer flere interessante grep som kan følges opp i større undersøkelser, slik som samarbeidet med institusjoner som vanligvis ikke inngår i sykepleieutdannelsen, og det direkte møtet med sosialt ekskluderte mennesker som en del av helseutdannelsen.

Øyvind Kvalnes og Einar Øverenget diskuterer etisk navigasjon for ledere i sin artikkel «Ethical Navigation in Leadership Training». Utgangspunktet for Kvalnes og Øverengets artikkel er ledere som jevnlig møter etiske utfordringer og dilemmaer i sitt virke. Hvordan kan man treffe gode etiske beslutninger? Er dette i det hele tatt noe man kan bli bedre på gjennom trening og målrettet arbeid? Kvalnes og Øverenget har et bekreftende svar på 
dette. «Navigasjonshjulet» er verktøyet de introduserer for lederen som vil trene på å møte etiske utfordringer i sin ledertilværelse på en god måte. Navigasjonshjulet er ment å ta høyde for alle de aspekter som er relevante for næringslivslederes etiske beslutninger. Fra helsevesenet kjenner vi «de fire prinsippers etikk», som har blitt et populært «navigasjonshjul» for helsevesenet i svært mange land. Kvalnes og Øverengets navigasjonshjul er spesialtilpasset næringslivslederens utfordringer. Deres erfaring etter mer enn ti års kontakt med næringslivet er at etisk trening er mulig, og at navigasjonshjulet er et verktøy som styrker refleksiviteten til lederne og artikulerer og kultiverer deres etiske oppfatninger.

I artikkelen «Organising Ethics: The Case of the Norwegian Army» foreslår EllenMarie Forsberg, Are Eidhamar og Svein-Tore Kristiansen en modell for hvordan en kan styrke en organisasjons kapasitet til å håndtere etiske utfordringer i organisasjonen. Artikkelen er basert på en studie av Forsvaret, men forfatterne hevder modellen kan anvendes på enhver organisasjon. Ut fra denne modellen skal tiltak i organisasjonen bygge på en empirisk identifisering av svake eller mangelfulle diskusjonsarenaer i organisasjonen. Denne empiriske undersøkelsen er strukturert og opplyst av Richard Scotts organisasjonsteori. Ett av forfatternes poenger er at tradisjonelle leverandører av normativ teori (som de identifiserer som filosofi og teologi) ikke alene gir tilfredsstillende redskaper for analyse og håndtering av organisasjonsetiske utfordringer. Her tydeliggjøres en av de metodiske og teoretiske kjerneutfordringer i anvendt etikk. Idet teorier fra ulike fagfelt inndras i normative analyser, synliggjøres behovet for å klargjøre disse teoriers normative forutsetninger. 